\title{
PEMBINAAN KARAKTER MAHASISWA MELALUI PERKULIAHAN BAHASA INDONESIA DI STIKES ALMA'ARIF BATURAJA
}

\author{
Eka Damayanti ${ }^{*}$
}

\author{
STIKES Alma'arif Baturaja
}

damayantiek12@gmail.com

\begin{abstract}
Abstrak
Pendidikan karakter telah menjadi pembahasan secara nasional. Mulai dari pusat hingga di daerah dan menjadi tanggung jawab utama bagi pelaksana pendidikan. Setiap pendidik berkewajiban untuk membina karakter generasi muda khususnya mahasiswa STIKES Alma'arif Baturaja. Hal ini menandakan bahwa dosen memiliki peran strategis di dalam membina dan mengembangkan karakter mahasiswa sehingga diperoleh karakter yang mencerminkan karakter manusia Indonesia. Pembentukan karakter bangsa tidak terlepas dari pembinaan karakter di lembaga pendidikan. Salah satu sarana yang dipandang strategis dalam membina karakter mahasiswa yakni melalui perkuliahan Bahasa Indonesia sebagai mata kuliah pengembangan kepribadian (MPK). Bahasa Indonesia memiliki fungsi yang luar biasa di dalam mengembangkan kepribadian bangsa, yakni senantiasa berkepribadian, berperilaku, dan berbudi bahasa khas Indonesia. Ketundukan penutur bahasa sesuai dengan tata krama serta sopan santun berbahasa akan menghasilkan masyarakat yang berbudi luhur dan berkarakter.
\end{abstract}

\section{Kata Kunci: Pendidikan Karakter, Mahasiswa, Bahasa Indonesia}

\section{PENDAHULUAN}

Dunia pendidikan menghadapi suatu masa yang sangat rumit di dalam pembentukan karakter remaja. Hal ini mengacu pada pandangan Lickona (2012:6) bahwa pengetahuan moral yang paling mendasar pun saat ini tampak perlahan menghilang dari kehidupan manusia yang berbudaya. Pandangan demikian didasarkan pada kenyataan tingkah laku remaja di Amerika Serikat. Bila dikaitkan pandangan yang dilontarkan oleh Lickona di atas dengan kenyataan karakter remaja Indonesia dewasa ini memang tidak jauh berbeda. Perilaku remaja Indonesia umumnya diwarnai dengan kekerasan, tawuran, narkoba, dan perilaku seks bebas. Hal ini tentu bertentangan dengan masyarakat Indonesia yang umumnya menganut agama Islam. Dengan demikian, maka pengetahuan moral yang paling mendasar pun saat ini tampak perlahan menghilang dari kehidupan manusia Indonesia yang notabenenya merupakan masyarakat yang berbudaya. Penataan budaya remaja yang berkarakter dapat dilakukan melalui proses berbahasa. Bahasa sangat berperan di dalam pembentukan karakter. Melalui cara berbahasa seseorang dapat diketahui karakter pribadinya. Antara bahasa dan kebudayaan memiliki keterkaitan yang berlangsung pada situasi kebahasaan dalam bentuk wacana atau perbincangan. Bahasa merupakan bagian yang tidak terpisahkan dari kehidupan manusia. Tanpa bahasa manusia tidak dapat melakukan hubungan sosial secara sempurna. Menurut Djojosuroto (2007: 92) "bahasa merupakan sarana komunikasi antar-manusia, tanpa bahasa tiada komunikasi”. Melalui kegiatan berbahasa, seseorang dapat berinteraksi dan berkomunikasi dengan sesama masyarakat. Keberadaan dan perkembangan bahasa selalu berubah seiring dengan perkembangan budaya masyarakat pemilik bahasa.

Melalui sarana bahasa, seseorang dapat menyampaikan pikiran, kehendak, dan perasaaan kepada orang lain. Bahasa juga dipandang sebagai cermin kepribadian seseorang karena bahasa diterjemahkan sebagai refleksi rasa, pikiran, dan tingkah laku penuturnya. Hal ini sesuai dengan pandangan Pateda (2005: 10) bahwa "bahasa adalah ucapan pikiran, kemauan, dan perasaan manusia yang bersistem, yang dihasilkan oleh alat bicara dan digunakan untuk berkomunikasi". Berdasarkan pandangan tersebut, maka peran bahasa dalam proses interaksi sosial tidak dapat digantikan dengan alat komunikasi manapun. Bahasa dimaksud adalah bahasa yang digunakan ketika seseorang melakukan kegiatan komunikasi dengan sesamanya. Orang yang menguasai bahasa Indonesia secara 
aktif dan pasif dapat mengekspresikan pemahaman dan kemampuan dirinya secara runtut, sistematis, logis, dan lugas. Hal ini dapat menandai kemampuan mengorganisasi karakter dirinya yang terkait dengan potensi daya pikir, emosi, keinginan, dan harapannya (Widjono, 2005:3). Mencermati pendapat tersebut, maka pembelajaran karakter melalui proses perkuliahan dipandang sangat strategis. Dosen memiliki peran yang penting dan menentukan berhasil atau tidaknya kegiatan pembinaan karakter yang dewasa ini gencar dilakukan di bidang pendidikan. Pentingnya pembinaan karakter mahasiswa melalui bahasa disandarkan pula pandangan Putra (2013:11) bahwa jika bahasa adalah perangkat simbol yang mencerminkan dan sekaligus menentukan pola pikir suatu kolektivitas manusia, maka hilangnya sebuah bahasa berarti juga hilangnya suatu perangkat simbol yang membentuk pola pikir tertentu. Pandangan ini menunjukkan bahwa antara pola pikir dan bahasa sangat erat hubungannya, karena bahasa menunjukkan pola pikir pemiliknya. Oleh karena itu, jika dewasa ini ketentuan berbahasa tidak mengikuti lagi norma-norma berbahasa, maka menimbulkan cara berbahasa yang tidak mencerminkan pola masyarakat yang hakiki.

Secara umum, karakter dimaknai sebagai cara berpikir dan berperilaku yang khas tiap individu untuk hidup dan bekerja sama, baik dalam lingkup keluarga, masyarakat, bangsa, dan negara. Scerenko (dalam Samani dan Hariyanto, 2012:42) mendefinisikan karakter sebagai atribut atau ciri-ciri yang membentuk dan membedakan ciri pribadi, ciri etis, dan kompleksitas mental dari seseorang, atau suatu kelompok, atau bangsa. Pada halaman yang sama Robert Marine mengambil pendekatan yang berbeda terhdapa makna karakter, menurutnya karakter adalah gabungan yang samar-samar antara sikap, perilaku bawaan, dan kemampuan yang membangun pribadi seseorang.

Samani dan Hariyanto (2012:43) mendefiniskan karakter sebagai nilai dasar yang membangun pribadi seseorang, terbentuk baik karena pengaruh hereditas maupun pengaruh lingkungan, yang membedakannya dengan orang lain, serta diwujudkan dalam sikap dan perilakunya dalam kehidupan sehari-hari. Pengertian tersebut menekankan dua hal, yakni karakter menjadi pembeda seseorang dengan orang lain, dan karakter diimplementasikan dalam kehidupan sehari-hari. Dalam Kamus Besar Bahasa Indonesia (2008:682) karakter bermakna sebagai tabiat, sifat-sifat kejiwaan, akhlak atau budi pekerti yang membedakan seseorang dengan orang lain, watak; sementara berkarakter diterjemahkan sebagai mempunyai tabiat atau mempunyai kepribadian. Sebagai wujud dari tabiat dan sifat, karakter ditelaah oleh Khan (2010:1) sebagai sikap pribadi yang stabil hasil proses konsolidasi secara progresif dan dinamis, intergrasi pernyataan dan tindakan. Sementara itu, karakter menurut pengamatan filsuf kontemporer bernama Michael Novak sebagaimana dikutip oleh Lickona (2012:81) merupakan campuran kompatibel dari seluruh kebaikan yang diidentifikasi oleh tradisi religius, cerita sastra, kaum bijaksana, dan kumpulan orang berakal sehat yang ada dalam sejarah.

Berdasarkan pengertian karakter yang telah dikemukakan di atas, maka dapat dipahami bahwa pembinaan karakter dilakukan melalui pendidikan, baik melalui pendidikan formal maupun nonformal. Melalui pendidikan, diharapkan setiap orang dapat mewujudkan karakter yang sesuai dengan nilai-nilai kemanusiaan. Pendidikan karakter berbasis potensi diri merupakan proses kegiatan yang mengarah pada peningkatan kualitas pendidikan dan pengem-bangan budaya harmoni yang selalu mengajarkan, membimbing, dan membina setiap manusia untuk memiliki kompetensi intelektual, sikap, dan keterampilan. Bergulirnya pendidikan yang berbasis karakter, hal ini menandakan bahwa ada nilai yang selama ini telah hilang dari dunia pendidikan. Betapa tidak, jika diperhatikan beberapa tahun terakhir sasaran akhir pembelajaran lebih ditekankan pada aspek kognitif. Persoalan sikap seakan telah diabaikan, sehingga lulusan SMA atau perguruan tinggi banyak yang tidak dikategorikan tidak bermoral. Apabila hal ini terus dibiarkan, maka bukan hal mustahil jika suatu saat akan terlahir masyarakat yang tidak bermoral. Oleh karena itu, menurut hemat penulis pendidikan karakter yang perlu dikembangkan adalah penanaman nilai dalam diri mahasiswa, baik itu nilai ketuhanan, nilai kemanusiaan, maupun nilai tentang alam. Pembiasaan dan pembentukan sikap akan hal-hal yang baik akhirnya akan membentuk karakter mahasiswa.

\section{METODE PENELITIAN}

Pembinaan karakter melalui proses perkuliahan sangat strategis dan tepat dilakukan. Mahasiswa akan tunduk dan patuh pada aturan main perkuliahan yang ditetapkan dosen di awal pertemuan. Dosen yang menetapkan suatu aturan main perkuliahan, pada dasarnya ia membentuk karakter mahasiswa, yakni karakter untuk disiplin dan jujur. Pembentukan dan pembinaan karakter mahasiswa melalui perkuliahan sejalan dengan pendapat MH Ainun Najib (dalam Darwis, 2013: 185) bahwa pengajaran dan

Eka Damayanti 
PEMBINAAN KARAKTER MAHASISWA MELALUI PERKULIAHAN BAHASA .... $\mid 49$ pembentukan karakter siswa/mahasiswa seyogyanya dilakukan secara terpadu dengan mata ajaran. Pandangan ini memberikan peluang dan kreativitas kepada dosen untuk mendesain pelaksanaan perkuliahan yang mengarah pada pembentukan dan pembinaan karakter mahasiswa.

Jika pembelajaran bahasa adalah sebuah proses pembentukan karakter manusia, maka pembelajaran bahasa Indonesia pada dasarnya merupakan sebuah proses pembentuk seorang individu menjadi manusia yang memiliki karakter Indonesia. Jika karakter orang Indonesia dianggap sebagai karakter yang ideal, maka pembentukan karakter Indonesia melalui bahasa Indonesia merupakan sebuah proses kebudayaan yang perlu didukung (Putra, dkk. 2013:xiv). Di dalam proses perkuliahan bahasa Indonesia, pembinaan karakter dilakukan dengan cara memberikan kritik atas pesan singkat yang dikirim mahasiswa kepada dosen ketika mengkonfirmasi jadwal perkuliahan. Berikut pesan singkat (SMS) mahasiswa.

\section{- Assalamu'alaikum... mohon maaf, sekedar mengingatkan bahwa bu ada jadwl besok mk bhsa indonesia pkul 08.35/09.35 d gedung baru rk 6 It 2 Trima ksih.}

(085299240971)

Pesan yang dikirim mahasiswa ditampilkan melalui slide power point, lalu dosen melakukan analisis. Analisis yang disampaikan yakni: 1) penggunaan bahasa Indonesia yang baik dan benar harus tetap diperhatikan walaupun melalui pesan singkat; 2) termasuk di dalamnya adalah penggunaan huruf kapital yang masih keliru. Apabila kedua hal tersebut dipatuhi dan dilakukan mahasiswa ketika berkomunikasi melalui pesan singkat, maka akan terbentuk karakter untuk menghargai bahasa dan berbudi bahasa yang santun. Memang diakui bahwa tugas membelajarkan bahasa Indonesia memiliki kendala yang sangat besar. Hal ini sesuai dengan pandangan Badudu (1992: 31) bahwa tugas guru bahasa Indonesia bukan tugas yang mudah dan jangan dianggap mudah, penyebabnya: 1) anggapan umum yang selalu memandang remeh bahasa Indonesia karena merasa sudah "tahu" berbahasa Indonesia; 2) pelajaran bahasa Indonesia itu sendiri yang biasanya kurang menarik minat siswa bila dibandingkan dengan mata pelajaran lain; 3) cara mengajar atau cara menyajikan materi yang tidak menarik sehingga membosankan siswa. Mengacu pada pandangan yang dikemukakan oleh Badudu di atas, maka dosen memiliki tantangan serius yang harus ditangani agar perkuliahan bahasa Indonesia yang disampaikan dapat menarik mahasiswa. Sebab, hal utama yang harus dipahamkan kepada mahasiswa adalah pentingnya pengembangan kecerdasan melalui penataan bahasa. Kecerdasan yang didukung oleh kepribadian dan moral yang tinggi memungkinkan setiap orang senantiasa menggali potensinya untuk dikembangkan menjadi kreativitas baru. Untuk mewujudkan kecerdasan dan kepribadian tersebut, mahasiswa dibekali keterampilan berbahasa yang secara alami diawali dengan pemahaman fungsi bahasa sebagai sarana komunikasi dalam berbagai ragam kebahasaan.

Fungsi bahasa Indonesia sebagai mata kuliah pengembang kepribadian diarahkan pada kemampuan berbahasa yang baik dan benar. Fungsi tersebut mencakup berbagai aspek: (1) mengembangkan kemampuan berkomunikasi ilmiah dalam berbagai media lisan maupun tulisan, (2) mengembangkan kemampuan akademis, (3) mengembangkan berbagai sikap, seperti sikap ilmiah, sikap paradigmatis dalam mengembangkan pola-pola berpikir, dan sikap terpelajar dalam mengaktualisasikan hasil belajarnya, (4) mengembangkan kecerdesan berbahasa, (5) mengembangkan kepribadian terutama dalam menciptakan kreatifitas baru yang terkait dengan pengalaman, pengetahuan, potensi, dan situasi baru yang dihadapinya, serta kemampuan mengekspresikannya, (6) mengembangkan kemampuan berkomunikasi antarpribadi sehingga memantapkan perkembangan pribadinya, dan (7) mengembangkan kemampuan sebagai lambang bangsa dan negara. Untuk itu, bahasa Indonesia harus mampu menghadapi pengaruh bahasa lain sehingga tetap berfungsi sebagai bahasa Negara Republik Indonesia. Betapa pentingnya pembentukan karakter manusia melalui norma-norma berbahasa sehingga menghasilkan generasi yang berbudi pekerti luhur dan berakhlak mulia dengan parameter yang tercrmin dalam aktivitas berbahasa. Apabila parameter berbahasa menjadi bagian dari penilaian dosen di dalam menentukan nilai akhir yang dicapai mahasiswa dalam suatu mata kuliah, maka lambat laun akan diperoleh suatu generasi yang berkarakter mulia. Tentu tercapai generasi mulia tidak akan dicapai dalam waktu yang singkat, tetapi memerlukan waktu yang cukup panjang. Akhirnya, mahasiswa akan dapat merealisasikan fungsi bahasa sebagaimana yang diisyaratkan oleh Widjono (2005: 11-12) berikut.

1) Bahasa sebagai Sarana Komunikasi

Bahasa Indonesia berfungsi sebagai alat komunikasi antaranggota masyarakat. Fungsi tersebut digunakan dalam berbagai lingkungan, tingkatan, dan kepentingan yang beraneka ragam, misalnya, komunikasi ilmiah, komunikasi bisnis, komunikasi kerja, dan komunikasi sosial, dan komunikasi 
budaya. Untuk itu, Anda diberi pengetahuan dan keterampilan menggunakan berbagai ragam bahasa yang dapat mendukung pengembangan pengetahuan, keterampilan, dan sikap ilmiahnya.

2) Bahasa sebagai Sarana Integrasi dan Adaptasi

Dengan bahasa orang dapat menyatakan hidup bersama dalam suatu ikatan. Misalnya: integritas kerja dalam sebuah institusi, integritas, kerawang dalam sebuah departemen, integritas keluarga, integritas kerja sama dalam bidang bisnis, integritas berbangsa dan bernegara, dan lain-lain. Integritas tersebut menimbulkan berbagai konsekuensi, misalnya harus beradaptasi dalam integritas tersebut sehingga tidak menimbulkan konflik, perpecahan, atau permusuhan.

3) Bahasa sebagai Sarana Kontrol Sosial

Bahasa sebagai kontrol sosial berfungsi untuk mengendalikan komunikasi agar orang yang terlibat dalam komunikasi dapat saling memahami. Masing-masing mengamati ucapan, perilaku, dan simbol-simbol lain yang menunjukkan arah komunikasi. Bahasa kontrol ini dapat diwujudkan dalam bentuk: aturan, anggaran dasar, undang-undang, dan lain-lain. Dalam kegiatan harian dapat berbentuk komunikasi timbal balik, baik secara lisan maupun tulisan. Dengan demikian, masingmasing dapat mengendalikan komunikasi yang hendak dituju. Mereka dapat saling memberi saran, kritik nasihat, tegur sapa, dan sebagainya. Kritik tajam dapat diterima dengan hati yang lapang jika kalimat yang dikemukakan memberikan kesan yang tulus tanpa prasangka.

Misalnya: laporan Anda akan lebih sempurna jika dilengkapi deskripsi data secara akurat. Laporan Anda akan lebih baik jika pengendalian variabel dilakukan secara konsisten. Laporan Anda terlambat kami terima sehingga tidak dapat diproses lebih lanjut. Sudah saatnya lembaga pendidikan ini menggunakan multi media dalam proses pembelajaran.

4) Bahasa sebagai Sarana Memahami Diri

Dalam membangun karakter seseorang harus dapat memahami dan mengidentifikasi kondisi dirinya terlebih dahulu. la harus dapat menyebutkan potensi dirinya, kekuatan dirinya, bakat, kecerdasannya, kemampuan intelektualnya, kemauannya, temperamennya, dan sebagainya. Pemahaman ini mencakup kemampuan fisik, emosi inteligensi, kecerdasan, psikis, karakternya, psikososial, dan lain-lain. Dari pemahaman yang cermat atas dirinya, seseorang akan mampu membangun karakternya dan mengorbitkannya kearah pengembangan potensi dan kemampuannya menciptakan kreativitas baru.

5) Bahasa sebagai Sarana Ekspresi Diri

Bahasa sebagai ekspresi diri dapat dilakukan dari tingkat yang paling sederhana sampai dengan tingkat yang kompleks atau tingkat kesulitan yang amat tinggi. Ekspresi sederhana, misalnya, untuk menyatakan cinta (saya akan senantiasa setia, bangga, dan prihatin kepadamu), lapar (sudah saatnya kita makan siang), kecewa (saya prihatin atas keputusan itu), dan sedih. Tingkat ekspresi diri yang kompleks dan berupa pernyataan kemampuan mengerjakan proyek-proyek besar dam bentuk proposal yang sulit dan rumit, menulis laporan (formal, artikel, teknis), menulis publikasi atas kemampuannya dalam berbagai media elektronik (website, diskusi melalui internet), dan menulis desain produk.

6) Bahasa sebagai Sarana Memahami Orang Lain

Untuk menjamin efektivitas komunikasi, seseorang perlu memahami orang lain, seperti dalam memahami dirinya. Dengan pemahaman terhadap seseorang, pemakai bahasa dapat mengenali berbagai hal mencakup kondisi pribadinya: potensi biologis, itelektual, emosianal, kecerdasan, karakter, paradigma yang melandasi pemikirnya, tipologi dasar temperamennya (sanguines, melankolis, kholeris, flagmatis), bakatnya, kemampuan kreativitasnya, kemampuan inovasinya, motivasi pengembangan dirinya, dan lain-lain. Melalui pemahaman orang lain yang dihadapinya secara cermat dan mendalam, seseorang akan memperoleh wawasan yang luas yang sangat bermanfaat dalam berbagai tingkat pergaulan, dalam penulisan sebuah cerita, drama, dan film. Selain itu, juga dapat diperoleh kemampuan berpikir sinergis dengan memadukan pengalaman orang lain bersamaan dengan potensi dirinya sehingga menghasilkan kreativitas baru yang khas. Pemahaman ini juga memungkinkan tercapainya keunggulan dalam berkompetisi.

Secara praktis, pembentukan karakter melalui perkuliahan bahasa Indonesia dilakukan dan ditata dalam silabus perkuliahan. Jenis karakter yang dikembangkan melalui perkuliahan bahasa Indonesia yaitu: mahasiswa menunjukkan perilaku jujur, disiplin, tanggung jawab, santun, dan percaya diri selama mengikuti perkuliahan dan menyelesaikan tugas-tugas perkuliahan. Karakter jujur yang ditekankan adalah penyelesaian tugas-tugas perkuliahan harus dilakukan secara mandiri, bukan hasil kerja orang lain. Termasuk karakter jujur yang diharapkan adalah penyelesaian tugas tidak boleh hasil

Eka Damayanti 
PEMBINAAN KARAKTER MAHASISWA MELALUI PERKULIAHAN BAHASA .... $\mid 51$ copy paste. Apabila ditemukan tugas copy paste, maka nilai tugas mahasiswa bernilai kosong. Kemudian karakter disiplin dua hal yang menjadi indikator, yaitu disiplin masuk kuliah dan disiplin menyelesaikan dan memasukkan tugas perkuliahan. Terkait dengan karakter tanggung jawab ditunjukkan oleh tanggung jawab mahasiswa ketika menyelesaikan tugas kelompok, termasuk pula tugas mandiri. Santun merupakan karakter yang dikembangkan dalam perkuliahan ini. Indikator mahasiswa dikatakan santun yakni terlihat ketika mahasiswa menggunakan bahasa, baik bahasa lisan maupun bahasa tulis. Apabila bahasa yang digunakan sudah baik dan benar, maka mahasiswa yang bersangkutan dianggap telah santun. Terakhir, karakter percaya diri paling penting, sebab mahasiswa yang mampu bersaing adalah mahasiswa yang memiliki rasa percaya diri yang kuat. Karakter percaya diri salah satunya terlihat ketika mahasiswa menyampaikan ide dan gagasan dalam kegiatan diskusi atau perkuliahan tanpa menunjukkan keraguan. Hal ini terus dilakukan dan dibiasakan sehingga mahasiswa berkarakter percaya diri yang kuat.

\section{HASIL DAN PEMBAHASAN}

Baik dan benar pembahasan tentang ragam bahasa tidak terlepas dari penggunaan bahasa oleh penuturnya serta situasi yang mendukung terjadinya proses berbahasa. Artinya, penggunaan bahasa sangat ditentukan oleh penutur dan dan situasi tutur yang mendukung. Pemakaian bahasa dalam situasi santai di rumah tidak dituntut bahasa baku, sebaliknya dalam situasi resmi sangat dituntut penggunaan bahasa yang baik dan benar (bahasa baku). Timbulnya ragam-ragam bahasa karena penggunaan bahasa sebagai media atau alat perhubungan (komunikasi tidak terlepas dari penuturnya atau masyarakat bahasanya (speech community) yang memiliki latar belakang budaya yang berbeda. Hal ini akan menimbulkan suatu masyarakat bahasa dengan ragam yang berbeda tetapi terdapat saling pengertian, dan atau sebahasa tetapi tidak terdapat saling pengertian, dan kemungkinan ketiga ialah bahasa yang dipergunakan berbeda tetapi terdapat saling pengertian (Alwasilah, 1985: 41-44). Menurut Sugono (1997: 10) ada tiga kriteria munculnya ragam bahasa, yaitu media yang digunakan, latar belakang penutur, dan pokok persoalan yang dibicarakan. Berdasarkan media yang digunakan, ragam bahasa dapat dibedakan atas ragam bahasa lisan dan bahasa tulis. Dilihat dari segi penuturnya, ragam bahasa dibedakan menjadi (i) ragam daerah (dialek), (ii) ragam bahasa terpelajar, (iii) ragam bahasa resmi, dan (iv) ragam tak resmi. Berdasarkan pokok persoalan yang dibicarakan, ragam bahasa dapat dibedakan atas bidang-bidang ilmu pengetahuan dan teknologi, misalnya ragam bahasa ilmu, ragam bahasa hukum, ragam bahasa niaga, ragam bahasa jurnalistik, dan ragam bahasa sastra.

Bahasa yang dihasilkan dengan menggunakan alat ucap dengan fonem sebagai unsur dasarnya disebut ragam bahasa lisan; sedangkan bahasa yang dihasilkan dengan memanfaatkan tulisan dengan huruf sebagai unsur dasarnya disebut ragam bahasa tulis. Untuk lebih jelasnya perbedaan ragam bahasa lisan dan ragam bahasa tulis diuraikan berikut. Pertama, ragam lisan memerlikan adanya lawan bicara yang siap mendengarkan apa yang diucapkan pembicara, baik berhadapan langsung atau tidak. Dalam ragam tulis tidak selalu memerlukan lawan bicara yang siap membaca apa yang dituliskan seseorang. Ragam lisan selalu memerlukan unsur-unsur fungsi gramatikal seperti subjek, predikat, objek, dan keterangan. Fungsi gramatikal tidak selalu dinyatakan dengan kata-kata. Unsur-unsur tersebut dapat dinyatakan dengan pralinguistik seperti isyarat, mimik air muka, dan gerak tubuh yang dapat mengungkapkan hal-hal tertentu. Berbeda dengan bahasa lisan, dalam bahasa tulis fungsi-fungsi gramatikal mutlak harus dinyatakan secara eksplisit. Hal itu perlu dilakukan agar pembaca tulisan itu mengerti apa yang dimaksud oleh penulis. Kedua, ragam lisan sangat terikat pada situasi, kondisi, ruang, dan waktu. Ragam tulis tidak demikian. Suatu putusan dalam ragam lisan baru dapat dimengerti oleh seseorang apabila dia berada atau terlibat di dalam situasi, kondisi, ruang, dan waktu yang sama. Artinya, apabila antara penutur dan pendengar saling berhubungan secara langsung.

Sebaliknya karya tulis seseorang dapat dibaca oleh pihak lain di mana ia berada tanpa berhubungan dengan penulisnya. Ketiga, tinggi rendah dan panjang pendek suara sangat berpengaruh dalam ragam lisan. Dalam ragam tulis tidak demikian, tetapi dilengkapi dengan tanda-tanda baca (fungtuasi) seperti: titik (.), koma (,), titik koma (;), titik berganda (:), tanda seru (!), dan tanda tanya. Bahasa Indonesia yang baik dan benar adalah penggunaan bahasa Indonesia yang sesuai dengan kondisi dan norma kemasyarakatan serta sesuai dengan kaidah bahasa baku bahasa Indonesia (Soeparno, ddk., 1997: 7). Dari pengertian itu, maka bahasa sudah dapat dikatakan baik apabila dapat dimengerti oleh komunikan kita dan ragamnya harus sesuai dengan situasi pada saat bahasa itu digunakan. Ragam bahasa yang dipakai oleh mahasiswa sewaktu mengobrol di kantin dan di

Eka Damayanti 
pemondokan memakai ragam dialek, karena hubungan sesame teman adalah salah satu contoh bahasa yang baik. Bahasa dikatakan tidak baik kalau sulit dimengerti oleh komunikan. Bahasa yang digunakan masyarakat yang sudah dikatakan baik, tidak dapat sepenuhnya digolongkan sebagai bahasa yang benar. Bahasa yang benar adalah bahasa yang sesuai dengan kaidah bahasa (Finoza, 2001: 11). Salah satu contoh bahasa yang benar adalah bahasa yang dipakai oleh para dosen pada saat memberi kuliah, atau seperti bahasa yang dipakai dalam rapat formal; lebih-lebih bahasa dalam temu ilmiah seperti diskusi dan seminar.

Apabila penggunaan bahasa dipertukarkan penggunaannya/pemakaiannya, misalnya dosen memakai ragam tidak resmi dalam situasi yang resmi, sudah jelas merupakan bahasa yang baik. Oleh karena itu, bahasa yang benar bisa menjadi tidak baik karena tidak sesuai dengan situasi pemakaiannya. Memperhatikan penjelasan di atas, maka yang dimaksud dengan bahasa Indonesia yang baik dan benar adalah bahasa Indonesia yang digunakan sesuai dengan norma kemasyarakatan yang berlaku. Misalnya, dalam situasi santai dan akrab tidak boleh digunakan bahasa Indonesia ragam baku. Bahkan komunikasi akan menjadi kaku dan tidak bergairah. Hendaknya digunakan bahasa Indonesia yang sesuai dan akrab atau bahasa nonbaku. Sebaliknya, apabila dalam situasi resmi kita tidak boleh menggunakan bahasa nonbaku, bahasa yang santai tetapi harus digunakan bahasa baku yaitu bahasa resmi dan bahasa formal. Kemudian bahasa Indonesia yang benar adalah bahasa Indonesia yang digunakan resmi dengan aturan atau kaidah tata bahasa Indonesia yang baku.

Dengan demikian maka yang dimaksud dengan bahasa Indonesia yang baik dan benar adalah bahasa Indonesia yang digunakan sesuai dengan norma kemasyarakatan yang berlaku dan sesuai pula dengan kaidah tata bahasa Indonesia baku. Adapun pengertian baik pada suatu kata (bentuk kata) atau suatu kalimat adalah pandangan yang diarahkan dari pilihan kata (diksi) yang sesuai dengan situasi tertentu. Pada suatu pertemuan sesuai dengan situasinya dapat dipakai kata, istilah, atau kalimat yang akan menimbulkan nilai rasa yang relevan dengan situasi itu. Misalnya pada suatu situasi kita mempergunakan kata menugasi, tetapi pada waktu lain yang situasinya berbeda kita akan menggunakan kata memerintahkan, meminta bantuan atau mempercayakan. Maknanya sama tetapi nilai rasa katakata tersebut berbeda karena situasinya yang berbeda pula. Demikian pula kita menggunakan kata mati, meninggal, wafat, dan sejenisnya sesuai situasi yang berbeda-beda.

Berdasarkan konsep bahasa Indonesia yang baik dan benar di atas, maka di dalam perkuliahan diberikan contoh penggunaan bahasa Indonesia oleh mahasiswa melalui pesan singkat. Bahasa yang digunakan mahasiswa melalui pesan singkat (SMS) dikaji bersama-sama dengan mahasiswa untuk menentukan apakah bahasa yang digunakan telah mencakup ciri-ciri bahasa Indonesia yang baik dan benar. Adapun jenis bahasa yang digunakan mahasiswa diuraikan berikut ini.

Assalamu'alaikum Wr.Wb maaf menganggu bu ini saya keting kelas A semester 2 sekedar mengigatkan bahwa besok ada mata kuliah BAHASA INDONESIA tepatnya besok pukul 08.10-09.10 Mohon infonya Wassalamu'alaikum Wr.Wb.

085941842196

Assalamu'alaikum w.r.b bu, maaf menganggu. Ini kelas C Semester 2. Hanya Memberi informasi bahwa esok ada Matakuliah-Nya ibu Bahasa Indonesia jam 08.40 Mohon infonya bu. Assalamualaikum w.r.b. bu, maaf menganggu. Ini keting kelas C Semester 2. Sekedar meminta konfirmasi mengenai Matakuliah 'Bahasa Indonesia' yang sempat ditunda hari jumat. Kira-kira kapan waktunya ibu memberi matakuliah tersebut. Mohon kejelasannya bu.

087845287782

Assalamualaikum wr.wb. maaf menganggu bu, hari ini ada jam kulia dikelas 2/E, jam 11:10 Balas! Irpan (keting)

087845157684

Assalamualaikum bu, maaf mengganggu. Saya mahasiswa bimbingannya ibu. Saya ingin berkonsultasi dengan ibu,,

085757481454

Ass Alaikum wr.wb. Minta maaf menggu bu, saya cman $m$ tanya sebentar ti ibu $m$ masuk? 
PEMBINAAN KARAKTER MAHASISWA MELALUI PERKULIAHAN BAHASA ... |53

Berdasarkan jenis pesan yang dikirim mahasiswa kepada dosen ketika hendak mengonfirmasi jadwal kuliah, biasanya mahasiswa yang bersangkutan menjadi malu, karena bahasanya diketahui oleh teman-temannya. Sebagai pengajar, dosen menegaskan bahwa contoh tersebut semata-mata diambil sebagai bahan pembahasan penggunaan bahasa Indonesia yang baik dan benar. Kemudian dosen dan mahasiswa membahas bersama contoh-contoh itu dilihat dari aspek bahasa Indonesia yang baik dan benar. Beberapa hal yang terungkap antara lain sebagai berikut.

1) Penerapan ejaan yang disempurnakan (EYD) harus tetap diperhatikan, walaupun itu melalui media handphone untuk menyampaikan pesan. Apalagi pesan tersebut ditujukan kepada dosen.

2) Penggunaan huruf besar dan huruf kecil yang tidak beraturan sebagaimana contoh yang ada, sepenuhnya tidak mencerminkan lagi penggunaan bahasa Indonesia yang benar. Sebab, bahasa Indonesia yang benar mengacu pada penggunaan bahasa Indonesia baku.

3) Terdapat penggunaan bahasa Indonesia yang tidak baik. Hal ini seperti yang terlihat pada pesan: "Assalamualaikum wr.wb. maaf menganggu bu, hari ini ada jam kulia dikelas 2/E, jam 11:10 Balas! Irpan (keting)." Munculnya kata "Balas" menyebabkan situasi berbahasa menjadi tidak baik, tidak sopan.

4) Mahasiswa harus tetap memperhatikan rambu-rambu pemakaian bahasa, sehingga bahasa yang dihasilkan adalah bahasa yang baik dan benar.

Berdasarkan hasil analisis terhadap contoh penggunaan bahasa yang ada, maka mahasiswa memiliki perubahan sikap berbahasa utamanya ketika mengirim pesan kepada dosen. Malahan mahasiswa yang lain berterima kasih atas dibahasnya bahasa yang mereka gunakan di dalam berkirim pesan, sebab dengan demikian, mereka menjadi tahu akan kesalahan yang masih mereka lakukan. Hal ini pun menjadikan motivasi tersendiri bagi penulis untuk selalu menampilkan pesan singkat (SMS) mahasiswa sebagai contoh penggunaan bahasa Indonesia yang baik dan benar untuk dibahas bersama mahasiswa.

\section{PENUTUP}

Berdasarkan hasil penelitian dan pembahasan dapat disimpulkan bahwa 1) Mata kuliah bahasa Indonesia merupakan sarana efektif untuk membina dan membentuk karakter mahasiswa melalui pembiasaan penggunaan bahasa Indonesia yang baik dan benar, baik secara lisan maupun tulisan. 2) Jenis karakter yang dikembangkan melalui perkuliahan bahasa Indonesia yaitu: mahasiswa menunjukkan perilaku jujur, disiplin, tanggung jawab, santun, dan percaya diri selama mengikuti perkuliahan dan menyelesaikan tugas-tugas perkuliahan. 3) Karakter mahasiswa salah satunya ditentukan oleh cara ia berbahasa, baik itu bahasa lisan maupun bahasa tulis. Hal ini menjadi tanggung jawab setiap pendidik untuk mengarahkan cara berbahasa mahasiswa. Pemberian contoh berbahasa oleh dosen mendukung kemampuan berbahasa yang baik bagi mahasiswa.

\section{DAFTAR PUSTAKA}

Alwasilah, A. Chaedar. 1985. Linguistik Suatu Pengantar. Bandung: Angkasa.

Badudu, JS. 1992. Cakrawala Bahasa Indonesia II.Jakarta. Gramedia Utama.

Darwis, Kamsinah. 2013. Sinergi Pengajaran Bahasa, Budaya, dan Agama dalam Pembentukan Karakter. Dalam Putra, Heddy Shri Ahimsa, dkk (ed). Bahasa, Budaya dan Karakter Manusia. Yogyakarta: Gama Media.

Djojosuroto, Kinayati. 2007. Filsafat Bahasa. Yogyakarta: Pustaka Book Publisher.

Finoza, Lamuddin. 2001. Komposisi Bahasa Indonesia: Suatu Pengantar. Jakarta: Kanisius.

Khan, Yahya. 2010. Pendidikan Karakter Berbasis Potensi Diri. Yogyakarta: Pelangi Publishing.

Lickona, Thomas. 2012. Mendidik untuk Membentuk Karakter. Jakarta: Bumi Aksara.

Pateda, Mansoer. 2005. Bahasa Indonesia di Perguruan Tinggi. Gorontalo: Viladan.

Putra, Heddy Shri Ahimsa, dkk. 2013. Bahasa, Budaya dan Karakter Manusia. Yogyakarta: Gama Media.

Eka Damayanti 
Samani, Muchlas, dan Hariyanto. 2012. Konsep dan Model Pendidikan Karakter. Bandung: Remaja Rosdakarya.

Soeparno, dkk. 1997. Bahasa Indonesia untuk Ekonomi. Yogyakarta: Ekonisia.

Sugono, Dendy. 1997. Inilah Bahasa Indonesia yang Baik dan Benar. Jakarta: Kanisius.

Wahyuni, Sri dan Abd. Syukur Ibrahim. 2012. Perencanaan Pembelajaran Bahasa Berkarakter. Bandung: Refika Aditama.

Widjono, HS. 2005. Bahasa Indonesia. Jakarta: Gramedia Widiasarana Indonesia. 